Ann. rheum. Dis. (1959), 19, 48.

\title{
PRODUCTION OF LUPUS ERYTHEMATOSUS (L.E.) CELLS IN THE DOG BY THE TRANSFUSION OF SYSTEMIC LUPUS ERYTHEMATOSUS PLASMA
}

BY

\section{GEORGE BENCZE}

\author{
WITH THE TECHNICAL ASSISTANCE OF \\ MARY LUDÁNYI \\ From the First Department of Medicine, University Medical School, Szeged, Hungary \\ (Director: Prof. M. Julesz)
}

The production of the lupus erythematosus cell phenomenon by the transfusion of lupus erythematosus plasma in three patients with malignant disease was the subject of an earlier report (Bencze, Cserhati, Kovacs, and Tiboldi, 1958). Numerous unsuccessful attempts have been made to produce L.E. cells in animals. The present paper reports the results of systemic lupus erythematosus (S.L.E.) plasma transfusion in six dogs, a seventh dog being used as a control.

\section{Method}

Plasma was obtained under sterile conditions from three patients with systemic lupus erythematosus (S.L.E.), in whose peripheral blood L.E. cells could be repeatedly demonstrated by the rotatory method of Zinkham and Conley (1956), using $10 \mathrm{ml}$. citrate to $100 \mathrm{ml}$. blood. The blood obtained in this way was kept for $24 \mathrm{hrs}$ at $4^{\circ} \mathrm{C}$., centrifuged for $15 \mathrm{~min}$. at 6,000 r.p.m., and incubated at $37^{\circ} \mathrm{C}$. for $30 \mathrm{~min}$. before use.

Each dog received a drip-transfusion of 4 to $5 \mathrm{ml} . / \mathrm{kg}$. body weight. Plasma from Donor 1 (K.E.) was given to Dogs 1 and 2, from Donor 2 (O.P.) to Dogs 3 and 4, and from Donor 3 (T.J.) to Dogs 5 and 6. The sixth dog received $50 \mathrm{ml}$. S.L.E. plasma and $50 \mathrm{ml}$. normal control plasma, and Dog 7 (Control) received normal plasma only (Table)

L.E. cells were looked for in the peripheral blood of the dogs before and immediately after the transfusion and at 30 minutes and 1, 2, 4, 6, 24 and $48 \mathrm{hrs}$ after the transfusion, by the method of Zinkham and Conley (1956).

\section{Results}

Experiment 1.-90 $\mathrm{ml}$. plasma obtained from Donor 1 (K.E.) was transfused into Dog 1 and $60 \mathrm{ml}$. into Dog 2. The transfusion was uneventful. A few L.E. cells could be found in the peripheral blood of Dog 1 for 6 hrs and in Dog 2 for 2 days $\stackrel{\infty}{\circ}$ (Figs 1 and 2, opposite).

Experiment 2.-60 ml. plasma obtained from $\overrightarrow{3}$ Donor 2 (O.P.) was transfused into Dogs 3 and 4. 옥 The transfusion was uneventful. Only a few L.E. $\vec{\bullet}$ cells could be detected after 1 and 2 hrs, but the 8 number then increased and reached the maximu $6 \mathrm{hrs}$ after the transfusion, when 50 to 60 L.E. ce per 1,000 leucocytes were present in Dog 4 as corit pared with 30 to 40 in the donor (Fig. 3, opposite).

Experiment 3.-Dog 5 received $90 \mathrm{ml}$. and Dog $6 \stackrel{\odot}{\odot}$ $50 \mathrm{ml}$. plasma from Donor 3 (T.J.). The trans- $\overrightarrow{\vec{O}}$ fusion was uneventful. No L.E. cells could be $\frac{3}{3}$ detected immediately after the transfusion but a few were seen after $30 \mathrm{~min}$. The maximum number was seen in each dog within 4 to $6 \mathrm{hrs}$ of the transfusion, 50 to 60 L.E. cells per 1,000 leucocytes being present as compared with 30 to 40 in the donor. $\frac{5}{3}$ The number of L.E. cells had fallen 24 hrs after the transfusion, but some were still present after 6 days 0 in Dog 5 and after 9 days in Dog 6 (Figs 4 and 5, opposite).

Experiment 4.-Normal human plasma obtained in a similar way was used in a control test.

$50 \mathrm{ml}$. normal plasma was given to Dog 624 days after the transfusion of S.L.E. plasma. During this $N$ second transfusion the animal developed nausea and $\mathcal{E}^{2}$ vomiting and experienced a state of shock. Adren-0 aline was administered subcutaneously and intra- 0

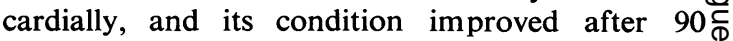
minutes.

The method of Zinkham and Conley (1956) showed no L.E. cells either immediately after 


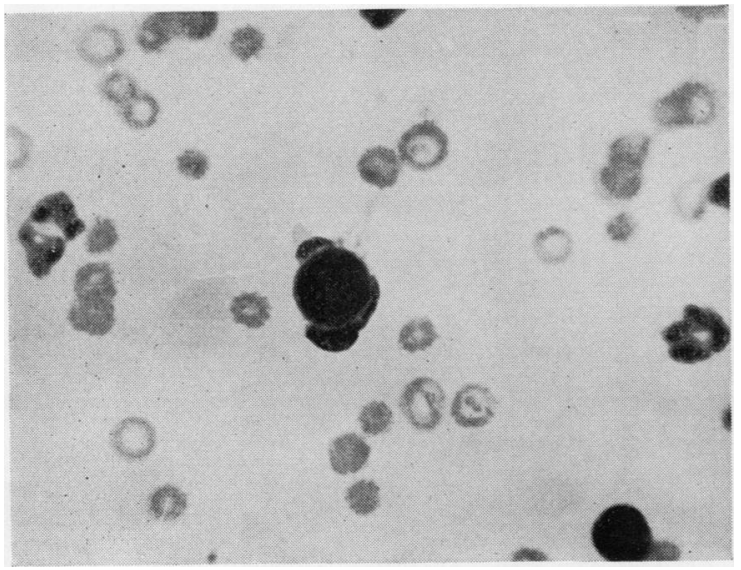

(1)

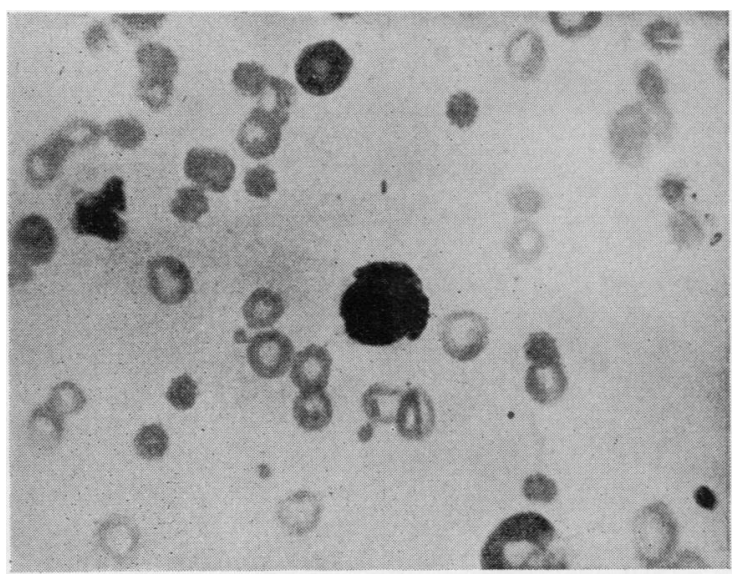

(3)

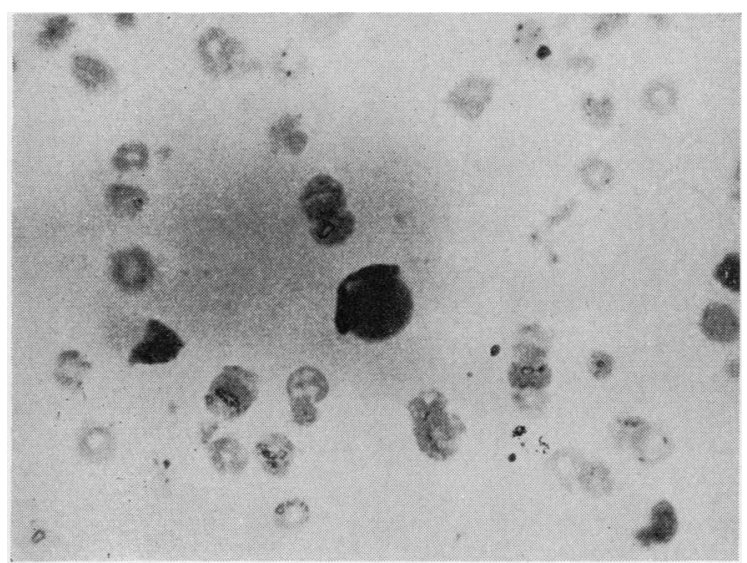

(5)

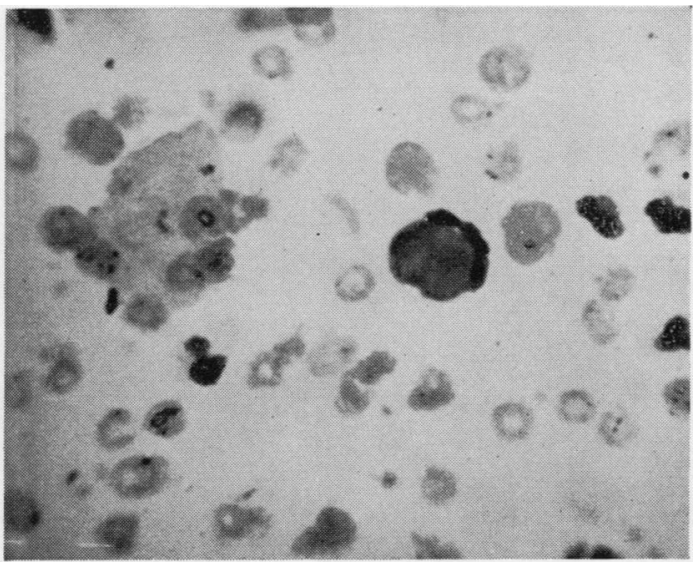

(2)

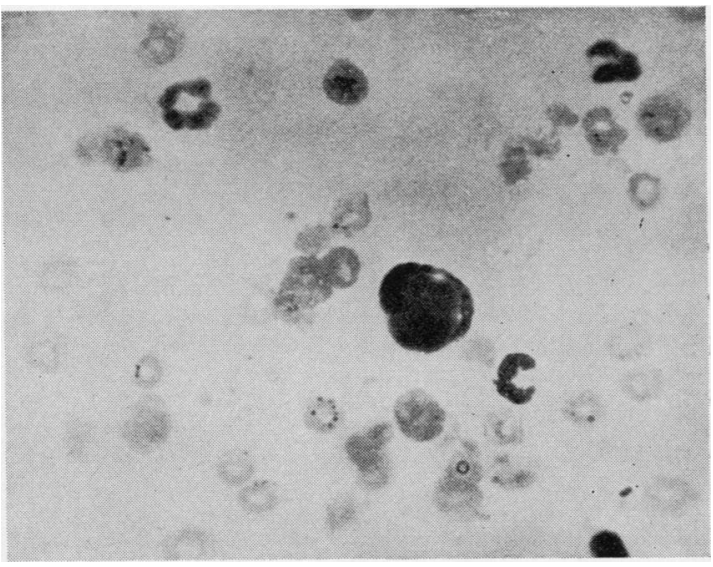

(4)

Fig. 1.-L.E. cell in peripheral blood of Dog 1, $60 \mathrm{~min}$. after plasma transfusion.

Fig. 2.-L.E. cell in peripheral blood of Dog 2, 2 hrs after plasma transfusion.

Fig. 3.-L.E. cell in peripheral blood of Dog 4, $6 \mathrm{hrs}$ after plasma transfusion.

Fig. 4.-L.E. cell in peripheral blood of Dog 5,6 days after plasma transfusion.

Fig. 5.-L.E. cell in peripheral blood of Dog 6, 9 days after plasma transfusion 
PRODUCTION OF L.E. CELL IN DOG BY

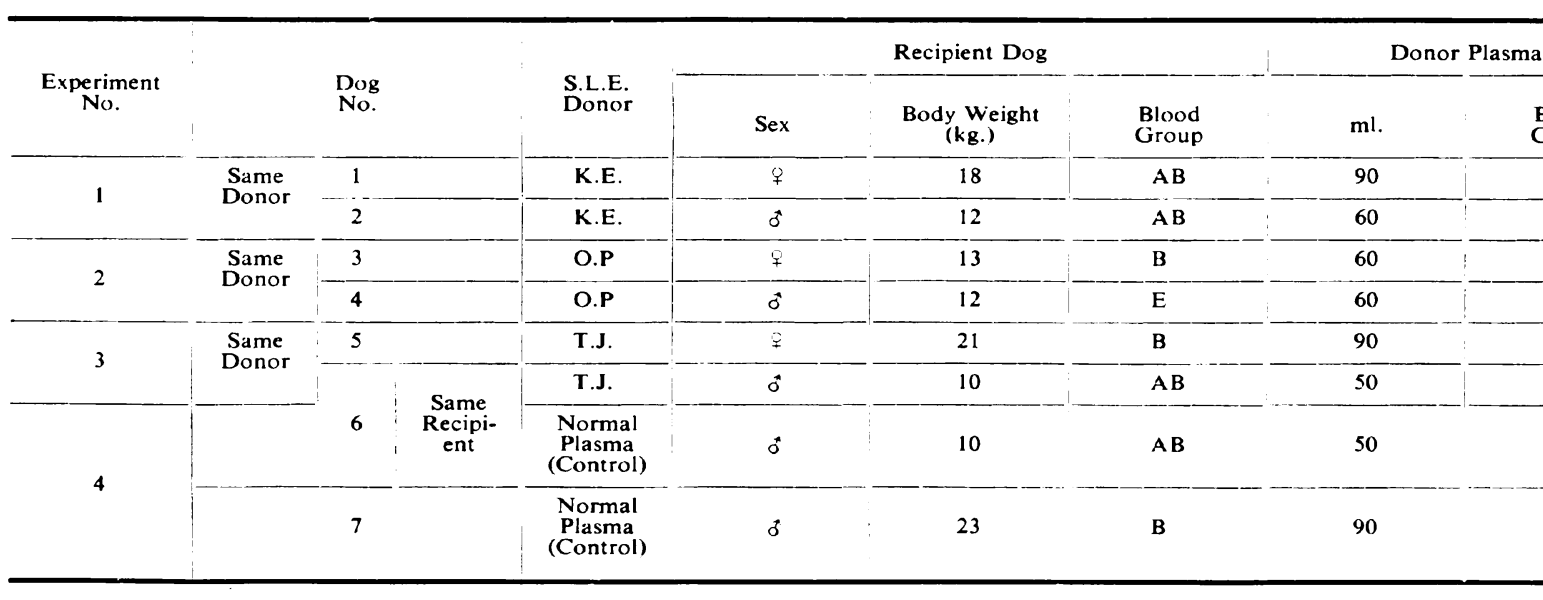

transfusion, or 30,60 , or $120 \mathrm{~min}$. later. Two hours after the transfusion the dog died suddenly, probably through bleeding due to the cardiac puncture.

No untoward response followed the normal plasma transfusion in Dog 7, and the results of L.E. cell examinations were negative.

The results of the four experiments are summarized in the Table.

\section{Discussion}

Transfusion experiments were carried out on six dogs with plasma obtained from three S.L.E. patients and a seventh dog was used as a control. After the plasma transfusion L.E. cells were found in all six dogs. The maximum was reached within 4 to 6 hours, when the number of L.E. cells in Dogs 4,5 , and 6 surpassed that in the blood of the donors. After 24 hrs the number of L.E. cells decreased.
In Dog 1 L.E. cells were present for 6 hrs, in Dog 2 for $48 \mathrm{hrs}$, and in the others for 3, 6, and 9 days respectively. Feulgen L.E. cells reactions were positive.

As a control normal plasma was given to Dogs 6 and 7. Dog 6, who had previously received S.L.E. plasma, developed severe shock and died 2 hrs later. L.E. cells were not found at all in Dogs 6 and 7 after the injection of normal plasma.

\section{Summary}

When L.E. cell positive plasma from patients with systemic lupus erythematosus was transfused into six dogs, typical L.E. cells were observed in all six animals, the maximum number of cells being seen 4 to 6 hrs after the transfusion. 
JSION OF LUPUS ERYTHEMATOSUS PLASMA

L.E. Cells in Recipients

\begin{tabular}{|c|c|c|c|c|c|c|c|c|c|c|c|c|c|c|}
\hline \multirow{2}{*}{ 3efore Transfusion } & \multicolumn{14}{|c|}{ Time after Transfusion } \\
\hline & $1 \mathrm{~min}$. & $30 \mathrm{~min}$. & $60 \mathrm{~min}$. & $2 \mathrm{hrs}$ & $4 \mathrm{hrs}$ & $6 \mathrm{hrs}$ & $24 \mathrm{hrs}$ & 2 days & 3 days & 4 days & 6 days & 7 days & 9 days & 10 days \\
\hline 0 & + & + & + & ++ & ++ & + & 0 & $\mathbf{0}$ & 0 & 0 & $\mathbf{0}$ & $\mathbf{0}$ & $\mathbf{0}$ & $\mathbf{0}$ \\
\hline 0 & + & + & + & + & + & + & + & + & 0 & 0 & 0 & 0 & 0 & 0 \\
\hline 0 & + & + & ++ & ++ & ++ & +++ & ++ & + & + & 0 & $\mathbf{0}$ & 0 & 0 & 0 \\
\hline & + & + & + & +++ & +++ & ++++ & ++ & ++ & + & $\mathbf{0}$ & 0 & 0 & 0 & $\mathbf{0}$ \\
\hline & $\mathbf{0}$ & + & ++ & + & ++++ & ++++ & ++ & ++ & + & + & + & 0 & 0 & 0 \\
\hline & 0 & + & +++ & ++++ & ++++ & ++++ & +++ & ++ & ++ & ++ & + & + & + & 0 \\
\hline 0 & 0 & 0 & 0 & $0^{*}$ & & & & & & & & & & \\
\hline 0 & 0 & 0 & 0 & 0 & 0 & 0 & 0 & 0 & 0 & $\mathbf{0}$ & 0 & 0 & 0 & 0 \\
\hline
\end{tabular}

* Succumbed 2 hours after transfusion.

\section{REFERENCES}

Bencze, G., Cserhati, S., Kovacs, J., and Tiboldi, T. (1958). Ann. rheum. Dis., 17, 426.

Zinkham, W. H., and Conley, C. L. (1956). Bull. Johns Hopk Hosp., 98, 102.

Production des cellules de lupus érythémateux (L.E.) chez le chien par transfusion du plasma des malades atteints de lupus érythémateux disséminé

RÉSUMÉ

Des transfusions du plasma des malades atteints de lupus érythémateux disséminé et contenant des cellules L.E. à six chiens, furent apparaître chez tous les six animaux des cellules L.E. typiques, atteignant un maxi- mum entre la 4-ème et la 6-ème heure après la transfusion.

Producción de células de lupus eritematoso (L.E.) en el perro por transfusión de plasma de enfermos con lupus eritematoso diseminado

\section{SUMARIO}

Transfusiones de plasma con células L.E. de enfermos con lupus eritematoso diseminado, a seis perros, resultaron en la presencia de células L.E. típicas en todos los animales, la mayoría de ellas evidenciada entre la cuarta y la sexta hora después de la transfusión. 